\title{
Recreation in Graeco-Roman Egypt
}

\author{
Mariam SAID
}

Noha SHALABY

\begin{abstract}
Recreation is an essential part of human life, which is usually reflected positively on the physical health and the general well-being of the individuals, thus contributing to the progress of the nations. Ancient Egyptians treasured leisure activities that were echoed in the level of advancement they have reached. Being under the GraecoRoman period, there was a continuity and change in the aspects of recreational activities in Egypt. This article aims to give an overview of recreation in GraecoRoman Egypt through studying various related materials.
\end{abstract}

Keywords: Graeco-Roman Egypt - Ptolemaic - recreation - leisure - hunting baths - music - drama - dance - games - festivals - gymnasia - clubs - palaestrae hippodrome.

\section{Introduction}

Ancient Egyptians had established a reputation for being prodigiously hard workers. Through such character trait, they reached very high level of sophistication in almost every sphere of knowledge. Meanwhile, they realized the value of balancing work and leisure, which was the key for the consistency of their productivity and success for nearly three millennia. Following such long era of sporadically interrupted independence of Egypt were about seven centuries of Macedonian and Roman rule. Both cultures undoubtedly treasured recreation and had their own approach to leisure through the provision of parks and gardens, theatres, gymnasia, baths, and stadia. The Graeco-Roman era in Egypt witnessed a continuity and change in the concept of recreation, the various aspects of which are discussed in this article through artifacts, buildings, and textual evidence with a special reference to the differences between Pharaonic and Graeco-Roman eras in Egypt.

\section{Leisure Sports and Activities:}

I. A. Hunting

It was among the most popular sports in Graeco-Roman Egypt. In ancient Egypt, hunting was limited to the wealthy and noble people, whereas in 
ancient Hellas it was practiced by all citizens of all social standards. ${ }^{1}$ Also, in Archaic and Classical Greece, hunters never used chariots as the Egyptians were doing, but for the most part they were on foot or riding horses. ${ }^{2}$ In ancient Rome, hunting was practiced by the farmers out of necessity, countrymen as a popular pastime, and aristocratic people as a sport; they were either on foot or on horseback depending on their social class. ${ }^{3}$ During the Graeco-Roman period in Egypt, fees were imposed by the state on hunting and fishing. ${ }^{4}$

In the Ptolemaic Period, the program of elephant hunting was introduced. ${ }^{5}$ They also established hunting stations where the parties used to capture elephants as far as Port Sudan in the south. ${ }^{6}$ Before the Second Syrian War, Ptolemy II sent an expedition to hunt African elephants that were mainly used for war purposes ${ }^{7}$ however, they were also used in the shows, of which the best example is the Great procession under Philadelphus. An account of such procession mentioned a long list of specimens since the hunters were keen to bring the king wide variety of animals to receive generous rewards. ${ }^{8}$ Sending expeditions for hunting elephants continued during the reign of King Ptolemy III and IV. It has been claimed that expeditions continued by Ptolemy V so as to replace the elephants lost in the battle of Raphia (217 BC) and to use them in quashing the revolts of the south until this tradition was abandoned during the $2^{\text {nd }}$ century BC..$^{9}$ As King Ptolemy II was interested in collecting and hunting animals; he especially established the zoological

${ }^{1}$ Ch. K. Sokos, M. N. Peterson, P. K. Birtsas and N. D. Hasanagas, "Insights for Contemporary Hunting from Ancient Hellenic Culture", Wildlife Society Bulletin 38/3, 2014, p. 452.

${ }^{2}$ J. M. BARringer, The Hunt in Ancient Greece, Baltimore and London, 2001, p. 2.

3 C. M. C. GReEN, "Did the Romans Hunt?", in Classical Antiquity 15, no. 2, Oct. 1996, p. $258,225$.

${ }^{4}$ M. RostovtzefF, A Large Estate in Egypt in the Third Century BC. A Study in Economic History, University of Wisconsin Studies in the Social Sciences and History 6, Madison, 1922, p. 112.

${ }^{5}$ L. CASSON, "Ptolemy II and the Hunting of African Elephants", in Transactions of the American Philological Association 123, 1993, p. 247.

${ }^{6}$ S. E. Sidebotham, Berenike and the Ancient Maritime Spice Route, The California World History Library 18, Berkley, Los Angelos and London, 2011, p. 45.

7 M. MizIUR, "Exotic Animals as a Manifestation of Royal luxuria. Rulers and Their Menageris: From the Pompe of Ptolemy II Philadelphus to Aurelian", Phasis 15-16, 20122013, p. 454.

${ }^{8}$ H. M. HubeLl, "Ptolemy's Zoo", in The Classical Journal 31, no. 2, Nov. 1935, p. 73-74.

${ }^{9}$ M. CoBB, "The Decline of Ptolemaic Elephant Hunting: An Analysis of the Contributory Factors", Greece and Rome 63, Issue 2, Oct. 2016, p. 193-194; P. FrASER, Ptolemaic Alexandria, Oxford, 1972, p. 178-179. 
garden of Alexandria where he could keep the animals. ${ }^{10}$ Scholars assumed that it was located within the palace area. ${ }^{11}$ However, the Romans were fond of hunting wild animals like jackals, bulls, snakes and crocodiles. ${ }^{12}$ It is not certain how many of the Ptolemaic hunting stations were still functioning under the Roman Rule. ${ }^{13}$

A considerable number of mosaics depicts the hunting of animals. There are two mosaics with hunting scenes found in Alexandria, preserved nowadays at the Graeco-Roman Museum in Alexandria. The first mosaic shows a naked hunter with a lance and round shield surrounded by a frieze of griffins and other animals (GRM Inv. 11125). ${ }^{14}$ The other mosaic represents a stag hunt by three Erotes surrounded by a frieze of real and mythical animals running around all the four sides (GRM Inv. 21738). ${ }^{15}$ The warriors hunted by using different tools such as sticks, swords, clubs, and lances. ${ }^{16}$

\section{B. Bathing}

It was a primal necessity in every culture. Though purity or cleanliness was a major practice in ancient Egyptian religion, public baths never existed in the Pharaonic Era. Private baths, however, were generally included in the royal palaces, houses of high officials and wealthy people. They were very simple

${ }^{10}$ P. G. P. MeYBoom, The Nile Mosaic of Palestrina: Early Evidence of Egyptian Religion in Italy, Religions in the Graeco-Roman World 121, Leiden and New York: Brill, 1995, p. 47; McK. JuDITH, The Architecture of Alexandria and Egypt: c. 300 B.C. to A.D. 700, London, 2007, p. 49.

${ }^{11}$ MizIUR, "Exotic Animals as a Manifestation of Royal luxuria", p. 454.

12 J. LINDSAY, Leisure and Pleasure in Roman Egypt, London, 1965, p. 194-195.

${ }^{13}$ Sidebotham, Berenike and the Ancient Maritime Spice Route, p. 45.

14 W. A. DASZEWSKI, "Corpus of Mosaics from Egypt. I., Hellenistic and Early Roman Period ", Verlag Ph. von Zabern - Mainz am Rhein, Mainz am Rhein, 1985, p. 101, cat. no. 1, pl. 1-3; Graeco-Roman Museum Database.

${ }^{15}$ DASZEWSKI, “Corpus of Mosaics from Egypt. I.", p. 160-161, pl. 34, 35 a.

${ }^{16}$ K. M. D. Dunbabin, Mosaics of the Greek and Roman World, Cambridge, 1999, p. 24, Fig. 22- 24. Worthy of note is that mosaic technique made its first debut in the Mediterranean region. The hypothetical theories claiming that the earliest mosaics were the small coloured cones of terracotta decorating the walls that were found in Sumer dating to the 4th millennium BC had been denied. This art was rather originated in Greece, from which the earliest surviving mosaics date to the late $5^{\text {th }}$ century BC. In Egypt, mosaics were found in Alexandria and its neighborhood, the region of the Nile Delta, the Fayum Oasis, Middle and Upper Egypt, and only few pieces came from Sinai Peninsula, see C. DAUPHIN, "The Graeco-Roman Legacy in the Levant", Classics Ireland 4, 1997, p.1-2; K. M. D. DunBabIN, Mosaics of the Greek and Roman World, Cambridge, 1999, p. 5; Z. HAWASS, Bibliotheca Alexandrina. The Archaeology Museum, Cairo, 2002, p. 53, W. A. DASZEWSKI, "From Hellenistic Polychrome of Sculptures to Roman Mosaics", Alexandria and alexandrianism: Papers Delivered at a Symposium Organized by the J. Paul Getty Museum and the Getty Center for the History of Art and the Humanities and Held at the Museum, April 22-25, 1993, Malibu, 1996, p. 145. 
and described as shallow stone pool, in which the person stood and let himself poured over with water from jugs. Poor population had to simply bathe in the Nile, or in their huts by sitting on the ground or in a terracotta receptacle and let water run over them, and water was poured out of the hut after bathing. ${ }^{17}$ Public bath, on the other hand, was a Greek innovation that was introduced to Egypt by the Greeks who were invited to settle in Egypt passing on their bathing practices to the Egyptians. ${ }^{18}$

In ancient Greek culture, bathing was regarded as a healthy and refreshing practice. It offered them pleasure, sense of well-being and recreation through relaxation, releasing the tension of the muscles by bath-tubs, and massaging their bodies with oil to moisturize their dried skin. ${ }^{19}$ The Greek example was originated in Greece in the $5^{\text {th }}$ century BC. Its evidence in Egypt can be traced back to the late $3^{\text {rd }}$ - early $2^{\text {nd }}$ century $\mathrm{BC}$; however it has been hypothesized to have emerged half a century earlier. It existed everywhere in Egypt. ${ }^{20}$ The Graeco-Egyptian baths can be classified into small and large public bath types. The small type had only one or two bathtubs. The large one included from 6 to 50 hip-bathtubs (usually an average of 42) as well as an average of three immersion bathtubs located in a separate rectangular room. Examples varied from one room having one bathtub to other rooms having up to five bathtubs. Thus the space allocated to hygienic bathing was considerably large compared to that assigned for relaxation. ${ }^{21}$ A characteristic feature of Greek baths in Egypt was that the baths were designed to be grouped around a central large corridor ${ }^{22}$ to give access to rooms with other bathing facilities such as repose, massage, personal hygiene, or ablutions, and medical services... etc. ${ }^{23}$ There were two main techniques used for decorating the Graeco-Egyptian baths: the mortar and mosaic technique;

17 A. ElKhACHAB, "TA $\Sigma$ APAПEIA à Sakha et au Fayum ou les bains thérapeutiques", Suppl. Ann. Serv. 25, 1978, pp. 5-6.

18 M. TRÜMPER, "Bath and Bathing, Greek", in C. SMITH (ed.), Encyclopedia of Global Archaeology, p. 786; S. M. NABEEH, Alhammamāt Ka-amāken Lel-'enāya Bel-gassad fi Misr fi Al-'asrein Al-Yōnāny wa Al-Romāny-Derāssah Atareyah Haḍareyah, Unpublished Master Thesis, Alexandria University, 2015, p. 174-175.

${ }^{19}$ F. YEGÜL, Baths and Bathing in Classical Antiquity, New York, 1992, p. 6.

${ }^{20}$ TH. Fournet, B. REDON, "Bathing in the Shadow of the Pyramids. Greek Baths in Egypt, Back to an Original Bath Model”, in B. REDON (ed.), Collective Baths in Egypt 2, Etudes Urbaine 10, Cairo, 2017, p. 117.

${ }^{21}$ Fournet and REDON, "Bathing in the Shadow of the Pyramids", p. 117; M. TRÜMPER, "Complex Public Bath Buildings of the Hellenistic Period. A Case Study in Regional Differences", in M.-F. Boussac, TH. Fournet, et B. REDON (eds.), Le Bain Collectif en Égypte, Études Urbaine 7, Cairo, 2009, p. 149.

${ }^{22}$ TRÜMPER, Études Urbaine 7, p. 149. For a list of large public complex Baths, cf. TRÜMPER, Études Urbaine 7, p. 149-50, n. 40.

${ }^{23}$ TRÜMPER, Études Urbaine 7, p. 140. 
however the former technique was the most common in Egypt. Both floor types were decorated with different motifs such as flowers, bands, animals. The walls were basically covered by a plaster layer, which sometimes held painted decoration. ${ }^{24}$ The mixing of men and women during bathing was not permitted in the Greek baths as there were two chambers (tholoi), one for men and the other for women. In the Roman Era, there were separate baths and mixed baths. The Greek baths in Egypt used the heating system (hypocaust), which heated the spaces under the surface of the room; however, this system became more sophisticated in the Roman period heating bathtubs or pools and the floors of the rooms as well. ${ }^{25}$

\section{C. Music ${ }^{26}$}

It had a long history in ancient Egypt. It was perfectly documented through the representations upon the walls of tombs and temples as well as the musical instruments that were mostly preserved in the graves. The earliest evidence can be traced back to the fourth or fifth dynasty. There were stringed and plucked instruments, wind instruments as well as percussions. Yet, there is no any kind of musical notation; it is likely that they possessed certain traditional melodies that were passed on from one generation to the other. $^{27}$

In the Graeco-Roman era, on the other hand, despite the very few pictorial documentation and the little remains of the musical instruments, ${ }^{28}$ there survived a different sort of material mainly through the terracotta figurines

${ }^{24}$ A.-M. Guimier-Sorbets, B. Redon, "The Floors of the Ptolemaic Baths of Egypt. Between Technique and Aesthetics", in B. REDON (ed.), Collective Baths in Egypt 2, Etudes Urbaine 10, Cairo, 2017, p. 142, 146, 150.

${ }^{25}$ Th. Fournet, B. ReDON, "Heating Systems of Greek Baths: New Evidence from Egypt", in S. K. LuCOrE, M. TRÜMPER (eds.), Greek Baths and Bathing Culture: New Discoveries and Approaches, BABesch Suppl. 23, Leuven, 2013, p. 239-63.

${ }^{26}$ For a comprehensive study on Music in Graeco- Roman Egypt, see M. SolimAN, La musique et les chansons en Egypte à l'époque Greco-Romaine. Unpublished Thesis, Cairo, 2018.

27 J. Pulver, "The Music of Ancient Egypt", Proceedings of the Musical Association 48th Sess., 1921 - 1922, p. 29-30, 47; "The Music of Ancient Egypt", The Musical Times 63, No. 948, 1922, p. 127; for a detailed study of the development of music in ancient Egypt, see H. HickmanN, Musicologie pharaonique, études sur l'évolution de l'art musical dans l'Égypte ancienne, 1956.

${ }^{28}$ For examples, cf. H. HICKMANN, Catalogue général des antiquités égyptiennes du musée du Caire. Instruments de musique, 1949, CGC 69521, 69282, 69286-69297, 69304, 6931569316, 69321-69323, 26650, 69852, 26658, 26663, p. 32, 44-48, 79-80, 82, 84, 146-147, 149-150; Graeco-Roman Museum Database Inv. Nos. 30421, 20040. 
and the music-related papyri. ${ }^{29}$ Perhaps the best examples of musicians' depictions are those shown on the walls of Hathor temple at Philae, ${ }^{30}$ the celebration of the triumph of Horus at Edfu temple, ${ }^{31}$ the musical scene on the gate of Mut Temple at Luxor, ${ }^{32}$ as well as the boy playing a set of piper at Wardian Tombs in Alexandria. ${ }^{33}$

Various musical instruments were used in Graeco-Roman Egypt by musicians and dancers in the cult feasts, banquets and public ceremonies. The most popular musical instruments in Graeco-Roman Egypt were bells, sistra, clappers, flutes, ${ }^{34}$ harps,${ }^{35}$ lyres,${ }^{36}$ trigonon, panpipes, ${ }^{37}$ tambourine, ${ }^{38}$ syrinx ${ }^{39}$ horns (trumpets) and castanets. ${ }^{40}$ Pharaonic instruments like the harp and sistrum continued to be used during the Graeco-Roman Era, while new instruments were introduced such as panpipes, aulos (double pipe) and bronze bells. Though double pipes were known during the Pharaonic era, the aulos $^{41}$ with its specific shape was not attested in Egypt before the Ptolemaic Period; it was a development of the oboe of the Pharaonic period. ${ }^{42}$ Bells were widely used in Graeco-Roman Egypt. They were made out of different

${ }^{29}$ CHR. VENDRIES, "Questions d'iconographie musicale: L'apport des terres cuites à la connaissance de la musique dans l'Égypte hellénistique et romaine", Greek and Roman Musical Studies 1, 2013, p. 196, 213.

${ }^{30}$ Fr. DAUMAS, "Les propylées du temple d'Hathor à Philae et le culte de la déesse", ZÄS 95, 1968, pl. I A 2, II B, III E, F, IV G, H, V I, K; Y. VoloKhINE, "Quelques aspects de Bès dans les temples égyptiens de l'époque Gréco-Romaine”, in L. BRICAULT, M. J. VersLuYS (eds.), Isis on the Nile. Egyptian Gods in Hellenistic and Roman Egypt, Proceedings of the IVth International Conference of Isis Studies, Leiden, 2010, p. 240, fig. 1.

${ }^{31}$ H. W. FAIRMAn, The Triumph of Horus. An Ancient Egyptian Sacred Drama, London, 1974, p. 105, fig. 13.

${ }^{32}$ S. SAUNERON, "La porte ptolémaïque de l'enceinte de Mout a Karnak", Mémoires Publiés par les membres de l'Institut Français d'Archéologie Orientale du Caire 107, Cairo, 1983, no. 9 , pl. 7.

${ }^{33}$ K. Bowman, Egypt after the Pharaohs, 332 BC - AD 642. From Alexander to the Arab Conquest, London, 1986, p. 90, fig. 54.

${ }^{34}$ For examples of flute players, see CGC 27926, 27927; Graeco-Roman Museum Inv. 23248.

${ }^{35}$ For terracotta harp players, see Graeco-Roman Museum Inv. 8063, 10477, 19501; Bibliotheca Alexandria Antiquities Museum BAAM 0322; Louvre AF 1054.

${ }^{36}$ For terracotta examples with lyre, see CGC 26763, 26853, 27087, 26793; Graeco- Roman Museum Inv. 24205.

${ }^{37}$ For an example of panpipes player, see British Museum GR 1925, 1120.1.

${ }^{38}$ For terracotta tambourine players, see Bibliotheca Alexandria Antiquities Museum BAAM 0731, 0714, 0753.

39 For terracotta syrinx players, see Graeco-Roman Museum Inv. 8059, 13293, 13294; CGC 26795.

${ }^{40}$ For terracotta figurine with castanets, see Ny Carlsberg Glyptotek Museum AE.I.N. 512.

${ }^{41}$ For terracotta figurine with Aulos, see the Egyptian Museum CGC 32823 (SR 5/4953).

${ }^{42}$ M. A. EL-KADY, "Aulos and Crotals in Graeco-roman Egypt", Journal of the General Union of Arab Archaeologists 3, Issue 3, Cairo, 2018, p. 80. 
materials such as bronze, gold and silver and were usually decorated with representations of the god $\mathrm{Bes}^{43}$ who was associated with music and pleasures of every kind and whose cult continued from the Pharaonic till the Graeco-Roman era.

Musicians gained a great popularity in Graeco-Roman Egypt. Many musicians' figurines showed deities, mainly (Harpokrates, Isis, and Bes) and other cult celebrants in religious festivals since cult practice was a common theme in Graeco-Roman Egypt. ${ }^{44}$ A considerable number of papyri discussed the leasing contracts of hired musicians including their wages. ${ }^{45}$ Also, musical games were commonly held as a kind of public entertainment during that period. These contests included singing and playing instruments such as the flute and lyre. ${ }^{46}$ They were normally held in the theater, and actors were sometimes awarded prizes during these festivals and plays. ${ }^{47}$

\section{D. Dancing}

Dancing with musical accompaniment was a primary source of entertainment and joy for the ancient Egyptians in the course of the celebration of religious festivals. It became much popular in Graeco-Roman Egypt; it may have been

${ }^{43}$ For an example of a bronze bell decorated with an image of Bes, cf. British Museum EA 6374, see E. A. W. Budge, The Mummuy: Chapters on Egyptian Funerary Archaeology, Cambridge: University of Cambridge Press, 1893, p. 287; C. GRAVES-Brown, Daemons and Spirits in Ancient Egypt, Cardiff: University of Wales Press, 2018, p. 53, 65 (n. 136).

${ }^{44}$ CHR. VENDRIES, "Questions d'iconographie musicale: L'apport des terres cuites à la connaissance de la musique dans l'Égypte hellénistique et romaine", Greek and Roman Musical Studies 1, 2013, p. 195.

${ }^{45}$ For examples, see B. P. GRENFELL, The Oxyrhynchus Papyri X. Edited with translations and notes by B. P. Grenfell and A. S. Hunt, London, 1914, p. 213-4; R. BURNET, L'Égypte ancienne à travers les papyrus. Vie quotidienne, Paris, 2003, p. 158-9, no. 9; A. C. JoHnson, An Economic Survey of Ancient Rome 2: Roman Egypt to the reign of Diocletian, Baltimore, 1936, p. 300, no. 187.

46 P.Col.8.226 = SB.5.7557 from El-Menya dating to the $\mathrm{II}^{\text {nd }}$ century AD, see W. L. WestermanN, "Entertainment in the Villages of Graeco-Roman Egypt", JEA 18, 1932, p. 16-17; M. VANDONI, Feste pubbliche e private nei documenti greci. A cura di Mariangela Vandoni, Milano- Varese, 1964, p. 33, no. 18; R. S. BAGNALL, T. T. RENNER, and K. A. WORP (eds.), Columbia Papyri VIII, Atlanta, 1990, p. 124- 125, pl. 36; http://www.papyri.info/hgv/27234, accessed on $14^{\text {th }}$ of March 2017.

${ }^{47}$ P. Oxy.7.1050 from El-Bahnasa dating to the II $^{\text {nd }}-$ III $^{\text {rd }}$ century AD, see A. S. HUNT, The Oxyrhynchus Papyri. Part VII. Edited with translations and notes by Arthur S. Hunt, London, 1910, p. 203-204; A. C. JOHNSON, An Economic Survey of Ancient Rome 2, p. 694695, no. 424. Another example is P.Oxy.47.3367 = P.Coll.Youtie.2.69 = Pap.Agon.9 from El-Bahnasa dating to III $^{\text {rd }}$ century AD, see R. COLES, M. W. HASLAM (eds.), The Oxyrhynchus Papyri. Part XLVII, Graeco-Roman Memoirs 66, London, 1980, p. 139-140. 
performed either by talented local villagers or by a troupe of dancers from the metropolis, who were hired at the local festivals of the village. ${ }^{48}$

Pygmies' dancing statues were found dating to this era. They were specifically brought from central Africa to take part in public and private entertainment. They were usually shown while dancing and playing different kinds of musical instruments. ${ }^{49}$ There is also a considerable number of terracotta dancing figurines for both males and females, as well as veiled and muffled female figurines described as dancers. ${ }^{50}$ Additionally, relief sculpture was also carved showing female dancers. ${ }^{51}$

Scenes of dancing pharaohs from the temples dating to the Ptolemaic and Roman periods are very rare. There are two scenes in the temple of Esna ${ }^{52}$ and two other scenes in the temple of Isis at Dendera ${ }^{53}$ and temple of Horus at Edfu ${ }^{54}$. These scenes show the pharaoh perform a ritual dancing before

\footnotetext{
${ }^{48}$ WeSTERMANN, "Entertainment in the Villages of Graeco-Roman Egypt", p. 18. For papyri with textual evidence of hiring dancers, see P.Grenf.2.67 from the Fayum dating to the III $^{\text {rd }}$ century AD, B. P. GRENFELL and A. S. HunT (eds.), New Classical Fragments and other Greek and Latin Papyri. Greek Paryri 2, Oxford, 1897, p. 67; R. BURNET, L'Égypte ancienne à travers les papyrus. Vie quotidienne, Paris, 2003, p. 165; and cf. P.Corn.9, P. SCHUBRT, Vivre en Égypte gréco-romaine, p. 154, no. 50; and cf. BGU.7.1648, BURNET, L'Égypte ancienne à travers les papyrus, p. 158, no. 8.

49 E. Z. H. QAdous, Fenoun Al-Eskandaria Al-qadeema, Alexandria, 2006, p. 65-66. For examples of dancing pygmies, see CGC 26848, JE 42032 (Egyptian Museum Database); GRM 9618, see F. HASSAN (ed.), Alexandria Graeco-Roman Museum. A Thematic Guide, Cairo, 2002, p. 144.

${ }^{50}$ D. M. BAILEY, Catalogue of the Terracottas in the British Museum IV. Ptolemaic and Roman Terracottas from Egypt, London, 2008, p. 133-134. For examples of terracotta dancing figures, see CGC 26723, JE 35654 (Egyptian Museum Database); Graeco-Roman Museum Inv. 22919, 22920, Ev. BrECCIA, Monuments de l"Égypte gréco-romaine. Tome deuxième. II. Terrecotte figurate greche e greco-egizie del Museo di Allessandria, Bergamo, 1934, pl. LVII, 281, 283; The Louvre Inv. AF. 1051, F. DunAND, Catalogue des terres cuites gréco-romaines d'Égypte, Paris, 1990, p. 198, no. 542. For examples of female dancers with head and face covered, see Graeco-Roman Museum Inv. 23198, BRECCIA, Monuments de l'Egypte Greco-romaine II, pl. LVIII, 284 (terra cotta); Metropolitan Museum of Art 1972.118.95, D. B. THOMPSON, "A Bronze Dancer from Alexandria", American Journal of Archaeology 54/4, 1950, p. 371-385, fig. 1-3.

${ }^{51}$ For examples, see TR 19.3.49.7 (Egyptian Museum Database); CGC 27577, 2727578, C. C. EDGAR, Catalogue général des antiquités égyptiennes du musée du Caire. Greek Sculpture, Cairo, 1903, p. 61, no. 27577, 27578, pl. XXIX.

${ }^{52}$ S. SAUneron, Le temple de Esna III, Cairo, 1968, p. 359, no. 382; J. Hallof, "Esna", in W. WENDRICH (ed.), UCLA Encyclopedia of Egyptology, Los Angeles, 2011, p. 6 and fig. 7 "Esna 520" (Both show Emperor Trajan dancing before the goddess Menhyt).

${ }^{53}$ S. CAuville, Dendara: Le temple d'Isis II, Le Caire, 2007, pl. 106-107.

${ }^{54}$ E. ChASsINAT, Le Temple d'Edfou V, MMAF 22, Cairo: IFAO, 1930, p. 373 - 374, pl. 141.
} 
different deities as he must accomplish a difficult mission to appease the furious goddesses. ${ }^{55}$

A remarkable mosaic was found at Tell Timai in Daqahliya Governorate shows a banquet scene among the Nilotic marshes, aquatic animals and pygmies dancing to entertain the guests. The guests are dressed in their best and greatly enjoyed listening to music, songs, watching the dancers, and drinking wine and eating from the table in front of them. ${ }^{56}$

\section{E. Drama}

Unlike what is universally believed that drama was originated in ancient Greece, public performances were initiated in ancient Egypt within ritual or religious context, which mainly took place in the temples during certain festivals or occasions. Most important documentation of Egyptian drama was through the Ramesseum Dramatic Papyrus, ${ }^{57}$ text of the triumph of Horus depicted at Edfu temple, and the dramatic rituals during the Khoiak Festival depicted at Dendera temple of Hathor. ${ }^{58}$ However, drama firstly came on stage by the Greeks. Papyri provided information about the location of theatrical buildings in Graeco-Roman Egypt (e.g. Alexandria, Arsinoe, Heracleopolis Magna, Oxyrhynchus, Antinoopolis... etc). ${ }^{59}$ The only surviving theater building was recovered at Alexandria in Kom El-Dikka near the center of the old city dating to the Roman Period. ${ }^{60}$ Also, the other

\footnotetext{
${ }^{55}$ HALLOF, "Esna", p. 6.

56 A. KASSEM, Fan Al-Fussayfessā' Al-Romāny. Al-Manāzer Al-Tabīaeya, Alexandria, 1998, p. 232-236; H. S. A. MAREI, Al-Mawdo 'at Al-Tasweereya ala Al-Fussayfessa' men Bedayet Al-'Asr Al-Batlamy hattā Nehāyet Al-'Asr Al-Bizantī fi Misr. Derāssa Moqarna ma' Šamāl Afriqia, unpublished Master thesis, Cairo University, 2015, p. 42-43, fig. 35-36; F. Hassan, M. El-AbBadi (et al.), Alexandria Graeco-Roman Museum. A Thematic Guide, Cairo, 2002, p. 145; M. J. VersLuYS, Aegyptiaca Romana. Nilotic scenes and the Roman views of Egypt, Religions in the Graeco-Roman World 144, Leiden - Boston, 2002, p. 198; H. Whitehouse, "Mosaics and Painting in Graeco-Roman Egypt", in A. B. Lloyd (ed.), A companion to Ancient Egypt II, Wiley-Blackwell, 2010, p. 1021.

${ }^{57}$ For a detailed study, cf. CH. GEISEN, The Ramesseum Dramatic Papyrus. A New Edition, Translation, and Interpretation, $\mathrm{PhD}$ Thesis, University of Toronto, 2012.

58 S. M. BIELESCH, "O Festival de Khoiak: a celebração dos ciclos do Renascimento", REVISTA ANGELUS NOVUS - n 2, 2011, p. 6-9; A. Z. OMARA, "Some New Evidence for the Khoiak Feast at Thebes", Egyptian Journal of Archaeological and Restoration Studies 9, Issue 1, Sohag, 2019, p. 62-63.

${ }^{59}$ A. Le BIAN, "Le théâtre d'Antioopolis", in R. PINTAUDI (ed.), Antinoupolis II, Firenze, 2014 , p. 223. For detailed information on dramatic performances and status of actors in Graeco-Roman Egypt, cf. D. AHMED, Al-Massāreh fi Misr fi Al-Asrein Al-Younāny wa AlRomāny wa Moqāranatha Bemassāreh Al-alam Al-Arabi (Al-Qesm Al-Afriqi-Al-Qesm AlAssyāwi) - Derāssah Tāreekheya Ațareyah Haḍāreyah, Unpublished Master Thesis, Alexandria University, 2011.

${ }^{60}$ E. QAdous, Atar Misr fi Al-'Asrein Al-Younāny wa Al-Romāny, Alexandria, 2001, p. 46, 52 .
} 
theaters, of which only remains were discovered, seem to be of Roman date as well. With the beginning of the Ptolemaic Period, Egypt witnessed a significant development of drama and theatrical practice. This passion for theater continued under the Roman rule when new forms of performances were introduced such as venationes (animal hunts) or munera (gladiatorial combats) that were taking place in the amphitheaters. They made a remarkable addition to the traditional pieces of Greek literature. ${ }^{61}$

Revealing the importance of theater and drama in Egypt during the GraecoRoman period are the numerous clay and bronze figurines of actors and the various kinds of theatrical masks - comic, dramatic and tragic - that were found dating to that period. Statuary examples show a man playing the role of a woman, a small boy playing the role of an elderly person... etc. Also, the statuettes of caricature actors reflect the popularity of the mime in that period. ${ }^{62}$ The prominent actors were regarded privileged people; they were selected for performing in the major religious festivals of the city that are related to god Dionysus. Furthermore, Hadrian spared actors from taxes, military services, and imprisonment. ${ }^{63}$

Papari preserved a number of dramatic texts indicating that the theaters (e.g. Oxyrhynchus Theater) may have staged Greek tragedies, comedies, and satyr plays. There are also examples providing lists of payments for theatrical entertainment including the amounts allocated to actors and to music and dancing. ${ }^{64}$ It is likely that inhabitants of a metropolis had occasional opportunities of watching classical works of Greek tragedy, funny folk shows and comic roles performed at the local theater. ${ }^{65}$

\section{F. Board Games}

The board games and gaming pieces found at the houses and tombs in Egypt dating to the Graeco-Roman era are not much different from those of the Pharaonic era. The movement of these games was determined either by throwing casting sticks, knuckle bones known in Greece as astragali, ${ }^{66}$ or

\footnotetext{
${ }^{61}$ Le BIAN, "Le théâtre d'Antioopolis", p. 223.

${ }^{62}$ HASSAN and El-ABBADI, Alexandria Graeco-Roman Museum, p. 148; BAILEY, Catalogue of the Terracottas in the British Museum IV, p. 136.

${ }^{63}$ HASSAN and El-ABBADI, Alexandria Graeco-Roman Museum, p. 148.

${ }^{64}$ M. A. MoHAmed, Al-Bahnassa fi Al-'asrein Al-Farāoni wa Al-Younāny - Al-Romāny: Derassah Atareyah Hadareyah, Unpublished Master Thesis, Cairo University, 2000, p. 104105.

${ }^{65}$ H. I. BELL, Egypt from Alexander the Great to the Arab Conquest: A Study in the Diffusion and Decay of Hellenism, Oxford, 1948, p. 83-84; M. M. A. IBRAHIM, Malämeh men Tareekh wa Hadaret Misr fi Al- 'asrein Al-Younāny wa Al-Romāny, Alexandria, 2011, p. 192.

${ }^{66}$ J. A. TYLDESLEY, Egyptian Games and Sports, Princes Risborough, 2007, p. 10-11.
} 
dice with dark engraved number of circles on each side. The latter is not believed to appear in Egypt before the Graeco-Roman era since only very few isolated examples were found from the Pharaonic period in Thebes and Amarna dating to XVIIIth Dynasty as well as a die from El-Lisht dating to XX Dynasty. ${ }^{67}$ Dice were used in one of the famous Egyptian local games, now known as backgammon. They were made of different materials such as bone, faience, limestone, wood, bronze and came from different towns like Bahnasa, Fayum... etc. ${ }^{68}$

One of the games introduced by the Greeks in Egypt was cottabos. It was usually played in drinking parties, in which small amount of wine was thrown at a mark such as a saucer floating in a krater, but shortly this game disappeared. ${ }^{69}$ A well-known Roman game called Ludus Latrunculorum is believed to have been created in the $1^{\text {st }}$ century AD in Alexandria based on the depiction of different buildings of Alexandria designated by their names on its gaming pieces, with a probability that it was a mixture of a Greek game and an Egyptian game, and then was adopted by the Roman World. ${ }^{70}$

\section{G. Children Toys and Games}

Generally, the majority of the archaeological evidence for children life, especially their toys and games, came from burials; however other toys have been found in the remains of houses. Infants were amused by wooden horses and birds on wheels, animals in clay (e.g. dogs, cats, camels, pigs, horses, rats, fish and lions) and balls. ${ }^{71}$ Many examples of children's toys and games were discovered dating to the Graeco-Roman period. ${ }^{72}$ Terracotta figures of toys were very common, especially those of animal figures; a lot of these toys

${ }^{67}$ W. C. HAYES, The Sceptre of Egypt. A Background for the Study of the Egyptian Antiquities in the Metropolitan Museum of Art II: The Hyksos Period and the New Kingdom (1675-1080 B. C.), New York, 1959, p. 405.

${ }^{68}$ E. FalKener, Falkener's Ancient Games - Games Ancient and Oriental, and How to Play them, Longmans, 2009, P. 458.

${ }^{69}$ LINDSAY, Leisure and Pleasure in Roman Egypt, p. 51.

${ }^{70}$ M. Rostovtzew, "Interprétations des tessères en Os avec figures, chiffres et legends", Revue Archéologique 5, (Janvier-Juin 1905), p. 124. On the other hand, Austin denies the probability that Ludus Latrunculorum was a mixture of Greek and Egyptian games, see R. G. Austin, “Roman Board Games II”, Greece \& Rome 4, no. 11, 1935, p. 81.

${ }^{71}$ M. M. RASLAH, Childhood in Graeco-Roman Egypt- Social Study, unpublished PhD thesis, Helwan University, Cairo, 2014, p. 240. For more details about the Toys and Games in Graeco-Roman Egypt, see A. H. Soleiman, Al'āb Al-Tasleya wa Al-Hewayāt fi Misr fi Al-'Asrein Al-Batlamy wa Al-Romāny ma 'a Derāssah Li-Magmo'āt Al-al'āb men hazehi AlFatrah Bel-Matahef Al-Masreyah, unpublished master thesis, Alexandria University, 2000.

${ }^{72}$ E. Z. H. Qadous, Fenoun Al-Eskandaria Al-Qadīma, 2006, p. 160. 
were found at Fayum. ${ }^{73}$ Another important site that revealed toys, dolls of papyrus or rags and dice gaming pieces was Oxyrhynchus. ${ }^{74}$

Toys of horses with wheels were not introduced in Egypt before the Roman Period $;{ }^{75}$ large number of these toys was found at Karanis in Fayum. ${ }^{76}$ Such wheeled horse toy was pulled by a string threaded through a hole in the horse's nose or neck, but unfortunately none was recovered with string attached. ${ }^{77}$ Also, there were other terracotta toys with representations of a boy or the god Harpocrates riding horse. ${ }^{78}$ Camel was one of the most common forms of toys ${ }^{79}$ fashioned with no attributes or loaded with goods so as to raise the awareness of the children regarding the role of the camel and its usage in human life. ${ }^{80}$ Also, other terracotta figurines of dogs,${ }^{81}$ cats, ${ }^{82}$ pigs,${ }^{83}$ birds or cocks ${ }^{84}$ were so favorable among the children.

Several types of dolls figurines were made of stone, wood, bone, terracotta, rags, textile or papyrus. They were frequently buried with the children, especially girls, like rag dolls with carved head and real hair, and parts of two or three different garments. ${ }^{85}$

${ }^{73}$ B. P. Grenfell, D. G. Hogarth, A. S. Hunt, Fayûm Towns and their Papyri. With a Chapter by J. Grafton Milne, GRM 3, London, 1900, p. 46.

74 B. P. GRenfell, A. S. Hunt, "Excavations at Oxyrhynchus (1896-1907)", in A. K. Bowman et al. (eds.), Oxyrhynchus: A City and its Texts, GRM 93, London, 2007, p. 359.

${ }_{75}^{75}$ TYLDESLEY, Egyptian Games and Sports, p. 27.

${ }^{76}$ J. BAINES, Cultural Atlas of Ancient Egypt, New York, 2000, p. 197.

77 QAdous, Fenoun Al-Eskandaria Al-Qadìma, p. 164; K. J. JoHnson, Materializing childhood: An historical archaeology of children in Roman Egypt, published $\mathrm{PhD}$ Thesis, University of Michigan, 2007, p. 89.

${ }_{78}^{78}$ RaSlaH, Childhood in Graeco-Roman Egypt, p. 109.

${ }^{79}$ Many examples of camel's toys were found in the group of the children's toys in the Graeco-Roman Museum at Alexandria. QADOUS, Fenoun Al-Eskandaria Al-Qadìma, p. 170171.

${ }^{80}$ E. Z. H. QADOUS, Hadaret Al-Eskandaria, Alexandria, 2012, p. 263.

${ }^{81}$ Figurines of dogs were particularly popular in Roman Egypt, cf. M. FJELDHAGEN, Catalogue Graeco-Roman Terracottas from Egypt: Ny Carlsberg Glyptotek, Copenhagen, 1995, p. 184.

${ }^{82}$ BAILEY, Catalogue of the Terracottas in the British Museum IV, p. 176.

${ }^{83}$ Children were fond of pigs because of its calm movement and soft body, many toys of which came from different cities such as Naukratis, Fayum and Alexandria, see QADOUS, Fenoun Al-Eskandaria Al-Qadìma, p. 168-170.

${ }^{84}$ Some examples have holes in the head, which were most probably made for strings so as to be pulled by the children; yet toys of wheeled birds were very few in Graeco-Roman Egypt when compared to those of horses and dogs, cf. RASLAH, Childhood in GraecoRoman Egypt, p. 109; QADOUS, Hadaret Al-Eskandaria, p. 270.

${ }^{85}$ W. M. F. PETRIE, Hawara, Biahmu, and Arsinoe, London, 1889, p. 12-13. 
Versions of common musical instruments are among the popular toys of children, such as the clappers consisting of a single elongated piece of wood with two claps attached on either side, rattles - much smaller in size and lighter than clappers - made of woven palm fiber and holding at one point some rattling material in the bulb, ${ }^{86}$ as well as bronze bells. ${ }^{87}$

\section{H. Festivals}

Many festivals were held during the Graeco-Roman era. ${ }^{88}$ They could be religious to honor the gods, or for another reason such as to honor the Ptolemaic kings or Roman emperors (e.g. accession of the king on the throne like Ptolemy II, birthdays festivals, celebrations of the deification, processions of victory and feasts of marriage). Different kinds of recreation took place including singers, musicians, dancers, actors, comic poets, lyric poets, tumblers as well as athletic competitions with prizes for the winners. ${ }^{89}$ Invitations to dinner festivals are very common in papyri ${ }^{90}$ from Roman Egypt; they were held in the temples or public buildings like the gymnasia. ${ }^{91}$

The earliest prominent festival in Graeco-Roman Egypt was Ptolemaieia ${ }^{92}$ in Alexandria. Apparently, it first took place in $280-279$ BC by Ptolemy II

\footnotetext{
${ }^{86}$ JOHNSON, Materializing childhood, p. 94.

${ }^{87}$ RASLAH, Childhood in Graeco-Roman Egypt, p. 87.
}

${ }^{88}$ For detailed information regarding this topic, see F. H. 'ABDEL-MALEK, Ala'yād wa AlEḥtefalāt fi Misr fi Al-'asr Al-Younāny wa Al-Romāny hattā Entešār Al-Massīḥeyah, unpublished PhD thesis, Al-Menoufeya University, 1994.

89 C. Escoffey, F. Cavoura, Ancient Alexandria, Alexandria, 2012, p. 32; J. Paul, Festivals and Contests in the Greek World, Los Angeles, 2011, p. 7- 8.

${ }^{90}$ For examples, cf. (P.Oxy.6.926 $=$ Chrest.Wilck.486) dating to the $3^{\text {rd }}$ century AD, see B. P. Grenfell and A. S. Hunt (eds.), The Oxyrhynchus Papyri VI. Nos. 845-1006, London, 1908, p. 292; (P. Fay.132 = Chr.Wilck.485) from Kasr El-Banat in the Fayum dating to the $3^{\text {rd }}$ century AD, see B. P. GRenfell, A. S. HunT and D. G. HogarTh, Fayûm Towns and Their Papyri, London, 1900, p. 288 (no. CXXXII); J. RowlandsON (ed.), Women and society in Greek and Roman Egypt. A source book, Cambridge, 1998, p. 319, no. 250c); (P.Oxy.36.2791) dating to $2^{\text {nd }}$ century AD, see ROWLANDSON, Women and society in Greek and Roman Egypt, p. 296-297, no. 232; R. BURNET, L'Égypte ancienne à travers les papyrus. Vie quotidienne, Paris, 2003, p. 236, no. 168; (P.Oxy.17.2147 = Sel.Pap.I.173) dating to the $3^{\text {rd }}$ century AD, see A. S. HUNT, The Oxyrhynchus Papyri XVII, London, 1927, p. 265; N. LEWIS, Life in Egypt under Roman Rule, Oxford, 1983, p. 46; (P.Oxy.3.523 = michigan.apis.1264) dating to the $2^{\text {nd }}$ century AD, see B. P. GRENFELL and A. S. HuNT (eds.), The Oxyrhynchus Papyri III, London, 1903, p. 260; (P.Oxy.1.110; chr.wilck.99) dating to the $2^{\text {nd }}$ century AD, see B. P. GRENFELL and A. S. HuNT (eds.), The Oxyrhynchus Papyri I, London, 1898, p. 177 (no. CX); VANDONI, Feste pubbliche e private nei documenti greci, no. 140.

${ }^{91}$ J. LinDSAY, Daily Life in Roman Egypt, London, 1963, p. 150; ESCOFFEY and CAVOURA, Ancient Alexandria, p. 32. For examples, cf. P.Oxy.36.2791, P.Oxy.17.2147, see n. 77.

${ }^{92}$ K. Bowman, Egypt after the Pharaohs, p. 24-25. For more details about the Grand Procession of Ptolemaieia, see E. E. RICE, The Grand procession of Ptolemy Philadelphus, 
Philadelphus in honor of his father Ptolemy Soter. It was a religious festival included musicians, ${ }^{93}$ dancers and athletic contests. ${ }^{94}$ Ptolemy II fixed its beginning every four years to the acronychal rising of Canopus. ${ }^{95}$ It was held in Hiera Nesos in the vicinity of Alexandria. Ptolemy II had high expectations for the athletic competitions at Ptolemaieia hoping to attain the same level as the Olympic Games in Ancient Greece; for that reason it was termed "Isolympic". Such dream did not come true since the level of contests was not as high as expected; accordingly by the $2^{\text {nd }}$ century BC Ptolemaieia no more existed. Winners in this festival were awarded several prizes like crowns, wreaths, and garlands. ${ }^{96}$

Another important festival initiated by Ptolemy Philadelphus is Theadelphia. It was assumed that it was held every four years like the Ptolemaieia based on the documents stating that visitors from other cities made only one visit to both festivals. It also included contests, in which local athletes were mainly involved. ${ }^{97}$ Furthermore, there existed a festival called the Basileia, which was held on Philadelphus' birthday where games and contests were included. $^{98}$

In the Roman Period, they were celebrating many festivals including the Souchia, Sarapeia, Kepouria, Isieia, Delia, Demetria, Rhodophoria, Panteleia and Merobollia. Some of these were Greek, i.e. they were being celebrated under the Ptolemies like Delia. There was also another celebration that was held in the New Year called Amesysia or Harvest-Festival. These festivals showed mixed elements from Egyptian and Greek cultures, of which the latter was prevalent. ${ }^{99}$

\section{Athletic/Physical Sports and Games:}

Although there were many kinds of sports and games in ancient Egypt, but there is no evidence for organized team sport or individual competition as a

Oxford, 1983, p. 225; E. E. RICE, "The Grand procession of Ptolemy Philadelphus", JEA 74, 1988, p. 291-292; A. DALBY, "Celebrating Hellenism far from Hellas: Feasts and Festivals of Ptolemy II of Egypt", in M. MCWILliams (ed.), Celebration Proceedings of the Oxford Symposium on Food and Cookery 2011, 2012, p. 88-89; S. REMIJSEN, "Greek Sport in Egypt: Status Symbol and Lifestyle", in P. Christesen, D. G. Kyle (eds.), A companion to Sport and Spectacle in Greek and Roman Antiquity, Wiley-Blackwell, 2014, p. 352-353.

${ }_{93}^{93}$ HASSAN and EL-ABBADI, Alexandria Graeco-Roman Museum, p. 114.

${ }^{94}$ BOWMAN, Egypt after the Pharaohs, p. 25.

${ }^{95}$ R. A. Hazzard, M. FitzGerald, "The Regulation of the Ptolemaieia", Journal of the Royal Astronomical Society of Canada 85/1, no. 628 (Feb. 1991), p. 6.

${ }^{96}$ REMIJSEN, "Greek Sport in Egypt”, p. 352- 353.

${ }^{97}$ REMIJSEN, "Greek Sport in Egypt", p. 353-354.

${ }^{98}$ REMIJSEN, “Greek Sport in Egypt”, p. 354.

${ }^{99}$ LINDSAY, Leisure and Pleasure in Roman Egypt, p. 32. 
public spectacle and/or architectural structures for sports before the arrival of Greeks and Romans. ${ }^{100}$ The games and contests held in ancient Egypt were mainly linked with religious festivals and events. New kinds of sports and games were introduced to Egypt by ancient Greeks and Romans. The winners were awarded prizes such as wreaths, ribbons, crowns, money, amphorae filled with olive oil, and treasures such as bronze tripods, big vases, or silver cups. Papyri provided abundant information in this regard, especially from Oxyrhnchus. ${ }^{101}$ Also, many statuettes of wrestlers, boxers and gladiators as well as mosaics ${ }^{102}$ dating to the Graeco-Roman era in Egypt shed the light on the athletic and sport life during that time. Some of the gladiators are from African origin; they lived in Egypt during the Hellenistic and Roman period, especially in Alexandria, and usually served as wrestlers or gladiators. ${ }^{103}$

In classical Greece, women's opportunities for sports life were very limited with the exception of the equestrian competition; they were not allowed to come near the Olympics area either to participate or watch. However, they were permitted to watch other athletic festivals elsewhere in Greece. In the Hellenistic world, females undoubtedly gained more rights and became involved in education, political and public life as well as sports. Females also sponsored gymnasia and took part in its educational systems. ${ }^{104}$

100 TYLDESLEY, Egyptian Games and Sports, p. 8.

${ }^{101}$ For examples, see J. R. REA (ed.), The Oxyrhynchus papyri XLIII, London, 1975, p. 67;

P. SCHUBERT, Vivre en Égypte gréco-romaine: une sélection de papyrus, Vevey, 2000,

p. 106-107, no. 25; COLES and HASLAM, "Oxyrhynchus Papyri XLVII", p. 139-140;

B. P. Grenfell and A. S. Hunt (eds.), The Oxyrhynchus Papyri VII, London, 1910, p. 204;

A. C. Johnson, An Economic Survey of Ancient Rome 2: Roman Egypt to the reign of Diocletian, Baltimore, 1936, p. 694-695, no. 424; (P.Oxy.27.2476) dating to 288 AD, see E. G. TURNER, J. REA, et al., The Oxyrhynchus Papyri XXVII, Graeco-Roman Memoirs 39, London, 1962, p. 169-71; B. P. GRenfell, A. S. Hunt, The Oxyrhynchus Papyri III, London, 1903 , p. $254-255$, no. 519 dating to the $2^{\text {nd }}$ century AD; JOHNSON, An Economic Survey of Ancient Rome 2, p. 694, no. 423; R. BURNET, L'Égypte ancienne à travers les papyrus. Vie quotidienne, Paris, 2003, p. 247-248, no. 182.

${ }^{102}$ For examples of such mosaics, cf. (BAAM Inv. 32045) dating back to the Hellenistic period, it shows two wrestlers combat at the gymnasium or a public bath, which reflects the athletic life of Greeks in Egypt and the new buildings appeared in Egypt for the first time during this era. The existence of a water fountain probably indicated that it was used by the two gladiators after the battle for bathing, see Z. HAWASS, The Supreme Council of Antiquities Archaeology Museum: Bibliotheca Alexandria, Egypt, 2002, p. 52; another mosaic (GRM Inv. 21740) represents an athlete at the bath for washing after exercising. Some common bath's tools, which were known from ancient Greece and Rome appeared in this scene such as the jar with a perfumed oil used for rubbing the body, and the strigile, which was used for scraping the skin and remove the dirt form it (Graeco-Roman Museum Database).

${ }^{103}$ EV. BRECCIA, Monuments de l'Égypte gréco-romaine II, 1934, p. 50.

${ }^{104}$ D. G. KYLE, Sport and Spectacle in the Ancient World, West Sussex, 2015, p. 214- 217. 
In Egypt, the Ptolemaic kings used sport as a way to confirm their Greek origin and to show themselves as being affluent and powerful. They established several athletic games and festivals in Egypt and built several structures for holding such events. ${ }^{105}$ Such games were mainly played in the wrestling arena (Palaestra) ${ }^{106}$ mentioned in many papyri. ${ }^{107}$ There were also other sports events which allow the amateurs from all classes to compete in boxing, wrestling, running, and other games. ${ }^{108}$

\section{A. Pankration}

It is a new sort of violence sports introduced in Egypt during the GraecoRoman era. The athletes in this sport used a combination between boxing and wrestling techniques. ${ }^{109}$ One of the most famous athletes in this sport was Marcus Aurelieus Asklepiades. ${ }^{110}$

\section{B. Panhellenic Games}

Such games appeared in Egypt for the first time during the Graeco-Roman era. They incorporated the Olympic Games, Isthmian Games, Nemean Games, and Pythian Games. They included foot races, wrestling, discus throwing, javelin throwing, pankration, and horse races, as well as music, dance, acting, and singing. Papyrus Oxy. XXVII 2476 explains the different events of Panhellenic games and the privileges which were granted for the winner athletes. Egyptian athletes participated in the Panhellenic games as they were regarded as citizens of Greek cities. ${ }^{111}$

\footnotetext{
${ }^{105}$ KYLE, Sport and Spectacle in the Ancient World, p. 215-216.

${ }^{106}$ On Palaestra, see infra, p. 93.

${ }^{107}$ For examples, cf. P.Cair.Zen.3.59440 = SB III 6998, see F. BILABEL, Sammelbuch Griechischer Urkunden aus Ägypten. Begründet im Auftrage der Strassburger Wissenschaftlichen Gesellschaft zu Heidelberg von Professor Dr. Friedrich Bilabel. Dritter Band, Berlin - Leipzig, 1926, p. 181-182, no. 6998.

${ }^{108}$ M. M. A. IBRAHIM, Malāmeh men Tareeh wa Hadāret Misr fi Al-'Asrein Al-Younāny wa Al-Romāny, Alexandria, 2011, p. 191.

109 D. G. KYLE, "Greek Athletic Competitions: The Ancient Olympics and More", in P. Christesen, D. G. KYle (eds.), A companion to Sport and Spectacle in Greek and Roman Antiquity, Wiley-Blackwell, 2014, p. 29,

${ }^{110}$ S. REMIJSEN, "Challenged by Egyptians: Greek Sports in the Third Century BC", The International Journal of the History of Sport 26, no. 2, 2009, p. 249. For information about Marcus Aurelieus Asklepiades, cf. L. MORETTI, Iscrizioni Agonistiche Greche, Signorelli, 1953, p. 79; A. H. HARRIS, "Notes on Three Athletic Inscriptions", Journal of Hellenic Studies 82, 1962, p. 19-20.

${ }^{111}$ S. REMIJSEN, "Challenged by Egyptians: Greek Sports in the Third Century BC", in Z. Papakonstantinou (ed.), Sport in the Cultures of the Ancient World, Routledge, 2010, p. $100-101$.
} 


\section{C. Chariot Races}

This sport had become one of the most widespread means of entertainment in Graeco-Roman Egypt. It was very common among the Ptolemaic kings; Ptolemy I won the first chariot race for a pair of colts at the Pythian festival in 314 BC, and Ptolemy II won at Olympia in 284 BC., as well as Ptolemy V and Ptolemy VI were both Panathenaic victors in the Mid-Second Century BC. ${ }^{112}$ This sport was not exclusive for the male members of the royal family; queens were encouraged to participate in such events. Arsinoe II and Berenice II won Olympic chariot races, yet it is not clear whether they only sent their chariots or went in person to spectate such contests in which their horses won. ${ }^{113}$

Papyri documents dating to late Roman Period show the program of a chariot race in the circus of Oxyrhynchus, accompanied by various forms of entertainment: P.Oxy.34.2707, P.Oxy.79.5215, P.Oxy.79.5216. ${ }^{114}$ Other documents also show the importance of charioteers and factions in Roman Egypt; a document displays the factions of Greens and Blues, which prevailed in the chief provincial towns as well as in the capital (P.Oxy.1.145). ${ }^{115}$

\section{D. Circus programs}

They included the most famous games of Roman Egypt at towns and villages where people enjoyed a great pleasure. Many depictions of circus riders, jugglers, and charioteers were found, ${ }^{116}$ as well as several papyri described different events of these programs. ${ }^{117}$

\footnotetext{
${ }^{112}$ M. Golden, Greek Sport and Social Status, Austin, 2004, p. 6; REMIJSEN, "Challenged by Egyptians", p. 101-102; D. G. KYLE, Sport and Spectacle in the Ancient World, West Sussex, 2015, p. 216.

${ }^{113}$ D. G. KYLE, Sport and Spectacle in the Ancient World, West Sussex, 2015, p. 216.

${ }^{114}$ P. SCHUBERT, Vivre en Égypte gréco-romaine: une sélection de papyrus, Vevey, 2000, p. 105-106, no. 24; W. B. HENRY, P. J. PARSONs et al., The Oxyrhynchus Papyri LXXIX, Graeco-Roman Memoirs 100, London, 2014, p. 183-184, 186.

${ }^{115}$ B. P. GREnfell and Hunt, The Oxyrhynchus Papyri I, p. 230 (no. CXLV) dating to the $6^{\text {th }}$ century AD.

${ }^{116}$ S. SANDRI, "Terracottas", in Chr. RigGS (ed.), The Oxford Handbook of Roman Egypt, Oxford, 2012, p. 641.

${ }^{117}$ For example, P.Oxy.2707 dating to the 6th century AD describes a circus program stating that there was a bill of six chariot races with dogs, gazelles, singing rope dancers, mimes and a troupe of athletes; see GOLDEN, Greek Sport and Social Status, p. 93.
} 


\section{E. Capitoline Games ${ }^{118}$}

They were held in many towns and villages of Roman Egypt; they included the equestrian races. Moreover, professional artists (e.g. musicians and dancers) were hired from different cities such as Arsinoe, Oxyrhynchus and Hermopolis. ${ }^{119}$ Winners were rewarded by their exemption from taxes and liturgies. ${ }^{120}$

\section{F. Actian Games}

They were among the most famous games held in Egypt during the Roman Era. These games refer to the competitive festivals, which were held in honour of the Roman Emperor Augustus to commemorate his victory over Antony and Cleopatra at the Battle of Actium in $31 \mathrm{BC}$. They included athletic, musical, and equestrian contests, and the winners were awarded prizes of wreaths of reeds linked to god Poseidon. ${ }^{121}$

\section{G. Gladiatorial Games}

These games have a long history in ancient Rome. They were not popular in ancient Egypt, yet they became very common in the Graeco-Roman era. Many statuettes of gladiators made of terracotta and bronze were found. These games were mainly held in the Amphitheater of Alexandria. It is noteworthy to mention that the one who was intended to be a gladiator had been treated as a slave and sometimes was beaten with iron materials until death. Therefore, a gladiator was not a prestigious occupation, but it was rather a kind of punishment. However, some gladiators were kindly treated and received gold from the emperors in case of winning the game. ${ }^{122}$

\footnotetext{
118 They were annual games held in ancient Rome. They were instituted by Camillus in honour of Jupiter Capitolinus, and in commemoration of the Capitol Hill. Contestants came from several places to participate in the different events of these games. Crowns and other prizes awarded for the poets and placed on their heads by the emperor. These games also included champions, oraters, comedians, magicians, historians... etc, see J. MILLAR, Encyclopedia Britannica: Or A Dictionary of Arts, Sciences, and Miscellaneous Literature; Enlarged and Improved 5, London, 1810, p. 159.

${ }^{119}$ A. LUKASZEWICZ, Studia Antiqua: Les édifices publics dans les villes de l'Égypte romaine Problèmes administratifs et financiers, Warszawa, 1986, p. 183.

${ }^{120}$ P.Oxy.43.3116 dating to the $3^{\text {rd }}$ century AD displays a petition of a winner at the two horse race of Capitoline games held at Antinoopolis; he is a resident of Oxyrhynchus and asks the strategist of Antinoopolis to confirm his exemption from taxes and liturgies that is considered as a reward for his victory at the Capitoline games, cf. SCHUBERT, Vivre en Égypte gréco-romaine, p. 106, 107, no. 25.

121 M. GoldEN, Sport in the Ancient World from A To Z, London, 2004, p. 2; E. M. ZAGHLOUL, Al-Hayah Al-Taqāfeyah wa Al-Riyādeyah wa Al-Fanneyah fi Oxyrinhus fi Al-'Asr Al-Romany hattā Nehāyat Al-Qarn Al-Talet Al-mīlādi fi dọ' Al-Wata'eq AlBardeyah, unpublished Master Thesis, Alexandria University, 2011, p. 94.

${ }^{122}$ LINDSAY, Leisure and Pleasure in Roman Egypt, p. 167-177.
} 


\section{H. Ephebic Games}

Ephebic displays held on the occasion of a religious festival, the accession of an emperor, or an imperial birthday, provided enjoyable spectacles for the inhabitants of the nome capitals in Graeco-Roman Egypt. There were periodic games, at which young teenage men of various classes competed in boxing, wrestling and running. ${ }^{123}$

When Hadrian founded Antinoopolis, the city was granted the right to build a circus to hold sacred games known as the Megala Antinoeia starting from 131 AD. Following that other metropolis proposed to establish ephebic games such as Oxyrhynchus in $210 \mathrm{AD}$ and Leontopolis in $220 \mathrm{AD}$. Both games were modeled after the Antinoeia, thus they were called Isantinoeios. ${ }^{124}$

\section{Recreation-Related Buildings}

Several new recreational buildings were established in Egypt during the Graeco-Roman era, of which the most famous are the Gymnasia, palaestrae, hippodromes, circuses, royal Palaces and public gardens and parks in addition to the previously discussed baths and theatres. These structures definitely reflect the influence of Greek and Roman cultural life in Egypt.

\section{A. Gymnasia}

Gymnasium is one of the most prominent features in ancient Greece and the most important sport institution all over the ancient world. It was transmitted to the east with the Greek immigrants; wherever Greeks settled in organized communities, a gymnasium would certainly be established since it was an integral part of any Greek community. ${ }^{125}$

The gymnasium was attended by young free-born male citizens or ephebes where they received physical and intellectual training. It was also the hub of their recreational activities. ${ }^{126}$ Gymnasia were also places of relaxation, social or public gatherings for sharing small talks and chatters as well as debating the serious subjects. ${ }^{127}$ On the other hand, Greek females were not permitted

123 REMIJSEN, "Greek Sport in Egypt", p. 352- 353. P.Oxy.4 $705=$ Chrest.Wilck.153 emphasized private endowments of 10,000 Attic drachmae for Ephebic contests, cf. R. BURNET, L'Égypte travers les ancienne à papyrus. Vie quotidienne, Paris, 2003, no. 82.

${ }^{124}$ REMiJSEN, "Greek Sport in Egypt", p. 357; S. REMIJSEN, "Greek Sport in Egypt: Status Symbol and Lifestyle", in P. Christesen, D. G. Kyle (eds.), A companion to Sport and Spectacle in Greek and Roman Antiquity, Wiley-Blackwell, 2014, p. 358.

${ }^{125}$ M. Rostovtzeff, The Social and Economic History of the Hellenistic World 2, Oxford, 1998, p. 1058-1059.

${ }^{126}$ RostovtzeFF, The Social and Economic History of the Hellenistic World 2, p. 1059.

${ }^{127}$ LINDSAY, Leisure and Pleasure in Roman Egypt, p. 97. 
to enter the gymnasia and participate in its events; it was exclusive for males in Egypt since it was not appropriate to see men naked while being physically trained. ${ }^{128}$ Worthy of note is that non-Greeks who have Greek identity, i.e. could speak Greek language and use Greek practices and legislation, were regarded as Hellenes despite their origin, and consequently they were admitted to Gymnasia. ${ }^{129}$ Documents from Egypt showed connection between the gymnasium and the Ptolemaic army. ${ }^{130}$ The latter is characterized by multi-ethnic participants (e.g. Egyptians, Persians, Libyans, Jews and Gauls), which is shown through the names of the army officers. They lived in the rural country and it was very likely for them to use the gymnasium for their military training. ${ }^{131}$

The earliest gymnasium structure in Egypt was built at Naukratis (Kom Ge'ief, Beheira) that was considered the oldest Greek city in Egypt. Gymnasia were built in Alexandria during the Ptolemaic period by the Greeks. ${ }^{132}$ Also, papyri indicated the existence of gymnasia or arenas for athletics in several capitals and cities of Egypt such as Luxor, Philadelpheia (Gharabet el-Gerza), Theadelphia (Batn-Ihrit), Aphroditopolis (Atfih), Herakleopolis Magna (Ihnasya el-Madina), and others. ${ }^{133}$

Recent discoveries of the German-Egyptian archaeological mission ${ }^{134}$ uncovered remains of the first Hellenistic gymnasium ever found in Egypt in the northwest of the Fayum on the site of Watfa, which was the location of

\footnotetext{
${ }^{128}$ LINDSAY, Leisure and Pleasure in Roman Egypt, p. 108.

129 D. Stavrou, The Gymnasion in the Hellenistic East: Motives, Divergences, and Networks of Contacts, PhD Thesis, University of Leicester, 2016, p. 37.

${ }^{130}$ C. A. Forbes, "Expanded Uses for the Greek Gymnasium”, Classical Philology 40, no. 1, (Jan. 1945), p. 38.

${ }^{131}$ StaVrou, The Gymnasion in the Hellenistic East, p. 168-169, n. 175.

${ }_{132}$ M. H. IBRAHIM, "Al-Gymnasion fi Misr fi Al-'Asr Al-Younāny wa Al-Romāny”, Derāsāt Sakandariah 2, Volume in honour of Prof. Mostafa Al-'Abbādi, Gam'iyāt Al-Atāar belAskandariah, Magazine 46, Alexandria, 2000, p. 14.

${ }^{133}$ IBRAHIM, "Al-Gymnasion fi Misr fi Al- Asr Al-Younāny wa Al-Romāny”, p. 14. For examples, cf. (P.Köln.1.52) from Antinoopolis dating to the $3^{\text {rd }}$ century AD, see B. KRAMER, R. HÜBNER, Kölner Papyri (P. Köln)1. Bearbeitet von Bärbel Kramer und Robert Hübner, Papyrologica Coloniensia 7, Opladen, 1976, p. 137-139; (P.Freib.4.70) from Theadelphia dating to early $3^{\text {rd }}$ century $\mathrm{AD}$, see R. W. DANIEL, M. GRONEWALD, H. J. Thissen, Griechische und demotische Papyri der Universitätsbibliothek Freiburg. Mitteilungen aus der Freiburger Papyrussammlung IV. Herausgegeben von Robert W. Daniel, Michael Gronewald und Heinz Josef Thissen, PTA 38, Bonn, 1986, p. 75; (P.Giss.1.50) from Oxyrhynchus dating to the 3rd century AD, see A. C. JoHnSON, An Economic Survey of Ancient Rome 2: Roman Egypt to the reign of Diocletian, Baltimore, 1936, p. 478, no. 305.

${ }^{134}$ The DAI Mission was headed by Prof. Cornelia Römer.
} 
the ancient village Philoteris, founded in the third century BC by King Ptolemy Philadelphus and named after his sister Philotera. ${ }^{135}$

During the Roman period, only the main towns of the city had a gymnasium such as Philadelphia, Theadelphia, Antinoopolis. A gymnasium bears the name of the Roman emperor Hadrian was found at Oxyrhynchus. There were also a gymnasium and thermal baths of Hadrian at Hermopolis. ${ }^{136}$ Moreover, gymnasia during that period had their own funding and financial resources from the state, from either the elite of the society or from the responsible of the gymnasium. ${ }^{137}$

\section{B. Palaestrae}

The palaestra originally refers to an area for wrestling. In time, it was described as structure with a square or oblong courtyard surrounded by rooms for various purposes such as undressing and oiling. It was either a stand-alone structure or a part of the gymnasium. Palaestra, however, did not include a race track (dromos) in its architecture like the gymnasium and was not designed to host sports competitions which require spacious areas. ${ }^{138}$ Free-standing palaestrae were found in many cities and villages of Egypt during the Ptolemaic period ${ }^{139}$ such as the palaestra of Heracleopolis. ${ }^{140}$

\section{C. Hippodrome}

The racecourse was among the places of entertainment, which appeared in Egypt for the first time during the Graeco-Roman period. The most famous Hippodrome was that of Alexandria located to the southwest of the city near the temple of Serapis. This structure served both as a hippodrome (for horseraces) and as a stadium (for athletics). It was called the Lageion in honor of king Ptolemy I's father, Lagos. During the Ptolemaic period, it was used for holding the Ptolemaieia games. In the Roman Period, it was used for chariot races, as well as for other different public events. ${ }^{141}$

\footnotetext{
135 http://english.ahram.org.eg/NewsContent/9/40/281045/Heritage/Ancient-Egypt/FirstHellenistic-gymnasium-in-Egypt-discovered-at.aspx.

136 A. M. AL-RoubY, Mazā̄her Al-Hayāh fi Misr fi Al-'Asr Al-Romāny: Egtemā'eyan wa Eqtesādeyan wa Edāreyan, Cairo, 1975, p. 49; LUKASZEWICZ, Studia Antiqua, p. 59; G. RoEDER, Hermopolis 1929-1939. Ausgrabungen der Deutschen Hermopolis-Expedition in Hermopolis, Ober- ̈̈gypten, in Verbindung mit zahlreichen Mitarbeitern. Herausgegeben von Günther Roeder, WVPM 4, Hildesheim, 1959, p. 126-8.

${ }^{137}$ Al-RoubY, Mazāher Al-Hayāh fi Misr fi Al-'Asr Al-Romāny, p. 49-52.

${ }^{138}$ J. DELORME, Gymnasion. Étude sur les monuments consacrés à l'éducation en Grèce (des origines à l'Empire romain), BEFAR 196, Paris, 1960, p. 262-71; GOLDEN, Sport in the Ancient World from A To Z, p. 122.

${ }^{139}$ IBRAHIM, “Al-Gymnasion fi Misr fi Al-'Asr Al-Younāny wa Al-Romāny”, p. 15.

${ }^{140}$ LUKASZEWICZ, Studia Antiqua, p. 59.

${ }^{141}$ EsCOFFEY and CAVOURA, Ancient Alexandria, p. 32.
} 


\section{D. Palaces}

In addition to the official functions, palaces in Graeco-Roman Egypt served ceremonial functions having reception and spacious audience hall which would normally had the throne as well where the king could meet his guests and subjects. The minor parties took place at smaller halls of the palace. Movable klinai and tables were common items of furniture inside palaces. Recreational elements including gardens and parks, pavilions, swimming pools, and game reserves played an important role in the architecture of palaces. ${ }^{142}$

\section{E. Camps}

Camps and tents were very popular especially among kings and elite individuals where recreational activities were taking place such as holding banquets, listening to music, watching dance and gaming. The most famous examples in Graeco-Roman Egypt were the tent of Alexander the Great and the banqueting tent of Ptolemy Philadelphus at Alexandria. ${ }^{143}$

\section{F. Social/Village Clubs}

Papyri were a clear evidence for the existence of clubs in the villages of Graeco-Roman Egypt. They were private institutions encompassing the elites of the villages who had to pay subscription for the membership. The administrative activities and the important business of the club (e.g. contracts with entertainers for shows and festivals) were in the hands of the presiding official, the hegoumenos. ${ }^{144}$ In such clubs, drinking-parties and dinner parties were held. These clubs, however, faced troubles under the Roman rule as illegal gatherings. ${ }^{145}$

In conclusion, the Egyptians throughout the Pharaonic era had their own approaches for recreation, which witnessed development and innovations under the Ptolemaic and Roman Rule. New forms of entertainment were introduced to Egypt that can fall into three different categories. The first, which is leisure activities, witnessed several innovations notably the public bath with all its practices, new musical instruments (e.g. panpipes), elephant hunting, dramatic performances including tragic and comic shows of the Greeks as well as venationes (animal hunts) or munera (gladiatorial combats)

\footnotetext{
${ }^{142}$ I. NIELSEN, Hellenistic Palaces: Tradition and Renewal, Aarhus, 1994, p. 26.

143 JuDith, The Architecture of Alexandria and Egypt: c. 300 B.C. to A.D. 700, London, 2007, p. 49; NIELSEN, Hellenistic Palaces, p. 21; M. PfROMMER, Alexandria im Schatten der Pyramiden, ZBA, Mainz am Rhein, 1999, p. 69-71; S. G. Miller, "Hellenistic Royal Palaces", in M. M. MiLES (ed.), A Companion to Greek Architecture, USA, 2016, p. 295.

${ }^{144}$ WESTERMANN, "Entertainment in the Villages of Graeco-Roman Egypt", p. 23-26.

${ }^{145}$ LINDSay, Daily Life in Roman Egypt, p. 150-151.
} 
of the Romans, new board games (e.g. cottabus of the Greeks and Ludus Latrunculorum of the Romans), children toys like the wheeled horse toy, as well as the festivals like Ptolemaieia, Theadelphia, Sarapeia, and Demetria. The second is the several Greek-style athletic games and sports such as Pankration, Capitoline, Actian, Ephebic, and Panhellenic games. The third category is the recreational buildings and institutions, of which most important are gymnasia, theatres, and social clubs. The non-Egyptian rulers and settlers from Greece and Rome carried their own tools of recreational culture to Egypt; such unique merge amongst three of the greatest civilizations of the ancient world undoubtedly enriched the sense of pleasure in Egypt that was certainly reflected in an overall better ambiance for its inhabitants.

\section{BIBLIOGRAPHY}

- 'Abdel-Malek (F. H.), Ala'yād wa Al-Ehtefalāt fi Misr fi Al-'asr AlYounāny wa Al-Romāny hattā Entešār Al-Massīheyah, unpublished $\mathrm{PhD}$ thesis, Al-Menoufeya University, 1994.

- AHMed (D.), Al-Massāreh fi Misr fi Al-Asrein Al-Younāny wa Al-Romāny wa Moqāranatha Bemassāreh Al-alam Al-Arabi (Al-Qesm Al-Afriqi-AlQesm Al-Assyāwi) - Derāssah Tāreekheya Atareyah Had̄āreyah, Unpublished Master Thesis, Alexandria University, 2011.

- Al-Rouby (A. M.), Mazāher Al-Hayāh fi Misr fi Al-'Asr Al-Romāny: Egtemā eyan wa Eqtesādeyan wa Edāreyan, Cairo, 1975.

- Austin (R. G.), "Roman Board Games II", Greece \& Rome 4, no. 11, 1935.

- Bagnall (R. S.), Renner (T. T.), and Worp (K. A.) (eds.), Columbia Papyri VIII, Atlanta, 1990.

- BAILEY (D. M.), Catalogue of the Terracottas in the British Museum IV. Ptolemaic and Roman Terracottas from Egypt, London, 2008.

- Baines (J.), Cultural Atlas of Ancient Egypt, New York, 2000.

- BARringer (J. M.), The Hunt in Ancient Greece, Baltimore and London, 2001.

- Bell (H. I.), Egypt from Alexander the Great to the Arab Conquest: A Study in the Diffusion and Decay of Hellenism, Oxford, 1948.

- BIElesch (S. M.), "O Festival de Khoiak: a celebração dos ciclos do Renascimento", Revista Angelus Novus - n 2, 2011. P. 5-33.

- BILABEL (F.), Sammelbuch Griechischer Urkunden aus Ägypten. Begründet im Auftrage der Strassburger Wissenschaftlichen Gesellschaft zu Heidelberg von Professor Dr. Friedrich Bilabel. Dritter Band, Berlin Leipzig, 1926.

- Bowman (K.), Egypt after the Pharaohs, 332 BC - AD 642. From Alexander to the Arab Conquest, London, 1986. 
- BrecCIA (EV.), Monuments de l"Égypte gréco-romaine. Tome deuxième. II. Terrecotte figurate greche e greco-egizie del Museo di Allessandria, Bergamo, 1934.

- Budge (E. A. W.), The Mummuy: Chapters on Egyptian Funerary Archaeology, Cambridge: University of Cambridge Press, 1893.

- BURNET (R.), L'Égypte ancienne à travers les papyrus. Vie quotidienne, Paris, 2003.

- CASsON (L.), "Ptolemy II and the Hunting of African Elephants", in Transactions of the American Philological Association 123, 1993, p. 247260.

- Cauville (S.), Dendara: Le temple d'Isis II, Le Caire, 2007.

- Chassinat (E.), Le Temple d'Edfou V, MMAF 22, Cairo: IFAO, 1930.

- CobB (M.), "The Decline of Ptolemaic Elephant Hunting: An Analysis of the Contributory Factors", Greece and Rome 63, Issue 2, Oct. 2016, p. 192-204.

- Coles (R.), Haslam (M. W.) (eds.), The Oxyrhynchus Papyri. Part XLVII, Graeco-Roman Memoirs 66, London, 1980.

- Dalby (A.), "Celebrating Hellenism far from Hellas: Feasts and Festivals of Ptolemy II of Egypt", in M. McWilliams (ed.), Celebration Proceedings of the Oxford Symposium on Food and Cookery 2011, 2012.

- Daniel (R. W.), Gronewald (M.), Thissen (H. J.), Griechische und demotische Papyri der Universitätsbibliothek Freiburg. Mitteilungen aus der Freiburger Papyrussammlung IV. Herausgegeben von Robert $W$. Daniel, Michael Gronewald und Heinz Josef Thissen, PTA 38, Bonn, 1986.

- Daszewski (W. A.), Corpus of Mosaics from Egypt. I., Hellenistic and Early Roman Period, Verlag Ph. von Zabern - Mainz am Rhein, Mainz am Rhein, 1985.

- DAszewski (W. A.), "From Hellenistic Polychrome of Sculptures to Roman Mosaics", Alexandria and Alexandrianism: Papers Delivered at a Symposium Organized by the J. Paul Getty Museum and the Getty Center for the History of Art and the Humanities and Held at the Museum, April 22-25, 1993, Malibu, 1996, p. 141-154.

- DAUMAS (Fr.), "Les propylées du temple d'Hathor à Philae et le culte de la déesse", Zeitschrift für Ägyptische Sprache und Altertumskunde 95, 1968, p. 1-17.

- DAuphin (C.), "The Graeco-Roman Legacy in the Levant", Classics Ireland 4, 1997, p. 1-32.

- Delorme (J.), Gymnasion. Étude sur les monuments consacrés à l'éducation en Grèce (des origines à l'Empire romain), BEFAR 196, Paris, 1960.

- Dunand (F.), Catalogue des terres cuites gréco-romaines d'Égypte, Paris, 1990. 
- Dunbabin (K. M. D.), Mosaics of the Greek and Roman World, Cambridge, 1999.

- Edgar (C. C.), Catalogue général des antiquités égyptiennes du musée du Caire. Greek Sculpture, Cairo, 1903.

- EL-KADY (M. A.), "Aulos and Crotals in Graeco-roman Egypt", Journal of the General Union of Arab Archaeologists 3, Issue 3, Cairo, 2018, p. 70-106.

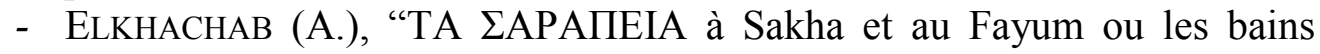
thérapeutiques", Suppl. Ann. Serv. 25, 1978.

- Escoffey (C.), Cavoura (F.), Ancient Alexandria, Alexandria, 2012.

- Fairman (H. W.), The Triumph of Horus. An Ancient Egyptian Sacred Drama, London, 1974.

- FalKener (E.), Falkener's Ancient Games - Games Ancient and Oriental, and How to Play them, Longmans, 2009.

- FJeldhagen (M.), Catalogue Graeco-Roman Terracottas from Egypt: Ny Carlsberg Glyptotek, Copenhagen, 1995.

- Forbes (C. A.), "Expanded Uses for the Greek Gymnasium", Classical Philology 40, no. 1, (Jan. 1945), p. 32-42.

- Fournet (Th.), Redon (B.), "Bathing in the Shadow of the Pyramids. Greek Baths in Egypt, Back to an Original Bath Model", in B. REDON (ed.), Collective Baths in Egypt 2, Etudes Urbaine 10, Cairo, 2017, p. 99138.

- Fournet (Th.), Redon (B.), "Heating Systems of Greek Baths: New Evidence from Egypt", in S. K. LuCORE, M. TRÜMPER (eds.), Greek Baths and Bathing Culture: New Discoveries and Approaches, BABesch Suppl. 23, Leuven, 2013, p. 239-263.

- Fraser (P.), Ptolemaic Alexandria, Oxford, 1972.

- CH. GeISEN, The Ramesseum Dramatic Papyrus. A New Edition, Translation, and Interpretation, $\mathrm{PhD}$ Thesis, University of Toronto, 2012.

- Golden (M.), Greek Sport and Social Status, Austin, 2004.

- Golden (M.), Sport in the Ancient World from A To Z, London, 2004.

- GreEn (C. M. C.), "Did the Romans Hunt?", in Classical Antiquity 15, no. 2, Oct. 1996, p. 222-260.

- Graves-Brown (C.), Daemons and Spirits in Ancient Egypt, Cardiff: University of Wales Press, 2018.

- Grenfell (B. P.) And Hunt (A. S.) (eds.), New Classical Fragments and other Greek and Latin Papyri. Greek Paryri 2, Oxford, 1897.

- Grenfell (B. P.) and Hunt (A. S.) (eds.), The Oxyrhynchus Papyri I, London, 1898.

- Grenfell (B. P.), Hogarth (D. G.), And Hunt (A. S.), Fayûm Towns and their Papyri. With a Chapter by J. Grafton Milne, GRM 3, London, 1900 . 
- Grenfell (B. P.) and Hunt (A. S.) (eds.), The Oxyrhynchus Papyri III, London, 1903.

- Grenfell (B. P.) and Hunt (A. S.) (eds.), The Oxyrhynchus Papyri VI. Nos. 845-1006, London, 1908.

- Grenfell (B. P.) And Hunt (A. S.) (eds.), The Oxyrhynchus Papyri VII, London, 1910.

- Grenfell (B. P.), The Oxyrhynchus Papyri X. Edited with translations and notes by B. P. Grenfell and A. S. Hunt, London, 1914.

- Grenfell (B. P.), Hunt (A. S.), "Excavations at Oxyrhynchus (18961907)", in A. K. BOWmAN et al. (eds.), Oxyrhynchus: A City and its Texts, GRM 93, London, 2007.

- Guimier-Sorbets (A.-M.), Redon (B.), "The Floors of the Ptolemaic Baths of Egypt. Between Technique and Aesthetics", in B. REDON (ed.), Collective Baths in Egypt 2, Études Urbaine 10, Cairo, 2017, p. 139-172.

- Hallof (J.), "Esna", in W. WendRICH (ed.), UCLA Encyclopedia of Egyptology, Los Angeles, 2011.

- HARRIS (A. H.), "Notes on Three Athletic Inscriptions", Journal of Hellenic Studies 82, 1962, p. 19-24.

- Hassan (F.), El-AbBadi (M.) (et al.), Alexandria Graeco-Roman Museum. A Thematic Guide, Cairo, 2002.

- Hawass (Z.), Bibliotheca Alexandrina. The Archaeology Museum, Cairo, 2000.

- Hawass (Z.), The Supreme Council of Antiquities Archaeology Museum: Bibliotheca Alexandria, Egypt, 2002.

- HAYES (W. C.), The Sceptre of Egypt. A Background for the Study of the Egyptian Antiquities in the Metropolitan Museum of Art II: The Hyksos Period and the New Kingdom (1675-1080 B. C.), New York, 1959.

- Hazzard (R. A.), FitzGerald (M.), "The Regulation of the Ptolemaieia", Journal of the Royal Astronomical Society of Canada 85/1, no. 628 (Feb. 1991), p. 6.

- Henry (W. B.), Parsons (P. J.) et al., The Oxyrhynchus Papyri LXXIX, Graeco-Roman Memoirs 100, London, 2014.

- Hickmann (H.), Catalogue général des antiquités égyptiennes du musée du Caire. Instruments de musique, 1949.

- Hickmann (H.), Musicologie pharaonique, études sur l'évolution de l'art musical dans l'Égypte ancienne, 1956.

- http://english.ahram.org.eg/NewsContent/9/40/281045/Heritage/AncientEgypt/First-Hellenistic-gymnasium-in-Egypt-discovered-at.aspx.

- http://www.papyri.info/hgv/27234.

- Hubell (H. M.), "Ptolemy's Zoo", in The Classical Journal 31, no. 2, Nov. 1935, p. 68-76.

- Hunt (A. S.), The Oxyrhynchus Papyri. Part VII. Edited with translations and notes by Arthur S. Hunt, London, 1910. 
- Hunt (A. S.), The Oxyrhynchus Papyri XVII, London, 1927.

- IBrahim (M. H.), "Al-Gymnasion fi Misr fi Al-'Asr Al-Younāny wa AlRomāny", Derāsāt Sakandariah 2, Volume in honour of Prof. Mostafa Al'Abbādi, Gam'iyāt Al-Ațār bel-Askandariah, Magazine 46, Alexandria, 2000.

- Ibrahim (M. M. A.), Malāmeh men Tareeh wa Hadāret Misr fi Al- 'Asrein Al-Younāny wa Al-Romāny, Alexandria, 2011.

- Johnson (A. C.), An Economic Survey of Ancient Rome 2: Roman Egypt to the reign of Diocletian, Baltimore, 1936.

- Johnson (K. J.), Materializing childhood: An historical archaeology of children in Roman Egypt, published PhD Thesis, University of Michigan, 2007.

- Judith (McK.), The Architecture of Alexandria and Egypt: c. 300 B.C. to A.D. 700, London, 2007.

- Kassem (A.), Fan Al-Fussayfessā̄' Al-Romāny. Al-Manāzer Al-Tabī'aeya, Alexandria, 1998, p. 232-236; H. S. A. MAREI, Al-Mawdo'at AlTasweereya ala Al-Fussayfessa' men Bedayet Al-'Asr Al-Batlamy hattā Nehāyet Al-'Asr Al-Bizantī fi Misr. Derāssa Moqarna ma' Šamāl Afriqia, unpublished Master Thesis, Cairo University, 2015.

- Kramer (B.), HÜBner (R.), Kölner Papyri (P. Köln)1. Bearbeitet von Bärbel Kramer und Robert Hübner, Papyrologica Coloniensia 7, Opladen, 1976.

- KYlE (D. G.), "Greek Athletic Competitions: The Ancient Olympics and More", in P. Christesen, D. G. Kyle (eds.), A companion to Sport and Spectacle in Greek and Roman Antiquity, Wiley-Blackwell, 2014, p. 2135.

- Kyle (D. G.), Sport and Spectacle in the Ancient World, West Sussex, 2015.

- Le Bian (A.), "Le théâtre d'Antioopolis", in R. Pintaudi (ed.), Antinoupolis II, Firenze, 2014.

- Lewis (N.), Life in Egypt under Roman Rule, Oxford, 1983.

- Lindsay (J.), Leisure and Pleasure in Roman Egypt, London, 1965.

- Lukaszewicz (A.), Studia Antiqua: Les édifices publics dans les villes de l'Égypte romaine Problèmes administratifs et financiers, Warszawa, 1986.

- Meyboom (P. G. P.), The Nile Mosaic of Palestrina: Early Evidence of Egyptian Religion in Italy, Religions in the Graeco-Roman World 121, Leiden and New York: Brill, 1995.

- Millar (J.), Encyclopedia Britannica: Or A Dictionary of Arts, Sciences, and Miscellaneous Literature; Enlarged and Improved 5, London, 1810.

- Miller (G.), "Hellenistic Royal Palaces", in M. M. Miles (ed.), A Companion to Greek Architecture, USA, 2016, p. 288-299. 
- Miziur (M.), "Exotic Animals as a Manifestation of Royal luxuria. Rulers and Their Menageris: From the Pompe of Ptolemy II Philadelphus to Aurelian", Phasis 15-16, 2012-2013, p. 451- 465.

- Mohamed (M. A.), Al-Bahnassa fi Al-'asrein Al-Farāoni wa Al-Younāny - Al-Romāny: Derassah Atareyah Hadareyah, Unpublished Master Thesis, Cairo University, 2000.

- Moretti (L.), Iscrizioni Agonistiche Greche, Signorelli, 1953.

- NABeeh (S. M.), Alhammamāt Ka-amāken Lel- enāya Bel-gassad fi Misr fi Al-'asrein Al-Yōnāny wa Al-Romāny- Derāssah Atareyah Haụareyah, Unpublished Master Thesis, Alexandria University, 2015.

- Nielsen (I.), Hellenistic Palaces: Tradition and Renewal, Aarhus, 1994.

- OMARA (A. Z.), "Some New Evidence for the Khoiak Feast at Thebes", Egyptian Journal of Archaeological and Restoration Studies 9, Issue 1, Sohag, 2019, p. 61-68.

- Paul (J.), Festivals and Contests in the Greek World, Los Angeles, 2011.

- Petrie (W. M. F.), Hawara, Biahmu, and Arsinoe, London, 1889.

- Pfrommer (M.), Alexandria im Schatten der Pyramiden, ZBA, Mainz am Rhein, 1999.

- Pulver (J.), "The Music of Ancient Egypt", Proceedings of the Musical Association 48th Sess., 1921 - 1922, p. 29-55.

- Pulver (J.), "The Music of Ancient Egypt", The Musical Times 63, No. 948, 1922, p. 127.

- QAdous (E. Z. H.), Atatar Misr fi Al-'Asrein Al-Younāny wa Al-Romāny, Alexandria, 2001.

- QAdous (E. Z. H.), Fenoun Al-Eskandaria Al-qadeema, Alexandria, 2006.

- QAdous (E.Z. H.), Hadaret Al-Eskandaria, Alexandria, 2012.

- Raslah (M. M.), Childhood in Graeco-Roman Egypt- Social Study, unpublished PhD thesis, Helwan University, Cairo, 2014.

- REA (J. R.) (ed.), The Oxyrhynchus papyri XLIII, London, 1975.

- Remisen (S.), "Challenged by Egyptians: Greek Sports in the Third Century BC", The International Journal of the History of Sport 26, no. 2 , 2009, p. 246-271.

- REMiJSEn (S.), "Challenged by Egyptians: Greek Sports in the Third Century BC", in Z. PAPAKOnSTANTINOU (ed.), Sport in the Cultures of the Ancient World, Routledge, 2010, p. 98-123.

- RemiJsen (S.), "Greek Sport in Egypt: Status Symbol and Lifestyle", in P. Christesen, D. G. Kyle (eds.), A companion to Sport and Spectacle in Greek and Roman Antiquity, Wiley-Blackwell, 2014, p. 349-363.

- RICE (E. E.), "The Grand procession of Ptolemy Philadelphus", Journal of Egyptian Archaeology 74, 1988, p. 290-292.

- RICE (E. E.), The Grand procession of Ptolemy Philadelphus, Oxford, 1983. 
- Roeder (G.), Hermopolis 1929-1939. Ausgrabungen der Deutschen Hermopolis-Expedition in Hermopolis, Ober-Ägypten, in Verbindung mit zahlreichen Mitarbeitern. Herausgegeben von Günther Roeder, WVPM 4, Hildesheim, 1959.

- Rostovtzew (M.), "Interprétations des tessères en Os avec figures, chiffres et légendes", Revue Archéologique 5, (Janvier-Juin 1905), p. 110124.

- Rostovtzeff (M.), A Large Estate in Egypt in the Third Century BC. A Study in Economic History, University of Wisconsin Studies in the Social Sciences and History 6, Madison, 1922.

- Rostovtzeff (M.), The Social and Economic History of the Hellenistic World 2, Oxford, 1998.

- Rowlandson (J.) (ed.), Women and society in Greek and Roman Egypt. A source book, Cambridge, 1998.

- SANDRI (S.), "Terracottas", in Chr. RigGS (ed.), The Oxford Handbook of Roman Egypt, Oxford, 2012.

- SAuneron (S.), Le temple d'Esna III, Cairo, 1968.

- SAUneron (S.), La porte ptolémaïque de l'enceinte de Mout à Karnak, Mémoires Publiés par les membres de l'Institut Français d'Archéologie Orientale du Caire 107, Cairo, 1983.

- SCHUbert (P.), Vivre en Égypte gréco-romaine: une sélection de papyrus, Vevey, 2000.

- Sidebotham (S. E.), Berenike and the Ancient Maritime Spice Route, The California World History Library 18, Berkley, Los Angelos and London, 2011.

- Sokos (Ch. K.), Peterson (M. N.), Birtsas (P. K.) and Hasanagas (N. D.), "Insights for Contemporary Hunting from Ancient Hellenic Culture", Wildlife Society Bulletin 38/3, 2014, p. 451-457.

- Soleiman (A. H.), Al'āb Al-Tasleya wa Al-Hewayāt fi Misr fi Al-'Asrein Al-Batlamy wa Al-Romāny ma'a Derāssah Li-Magmo'āt Al-al'āb men hazehi Al-Fatrah Bel-Matahef Al-Masreyah, unpublished master thesis, Alexandria University, 2000.

- Soliman (M.), La musique et les chansons en Egypte à l'époque GrecoRomaine. Unpublished Thesis, Cairo, 2018.

- Stavrou (D.), The Gymnasion in the Hellenistic East: Motives, Divergences, and Networks of Contacts, $\mathrm{PhD}$ Thesis, University of Leicester, 2016.

- Thompson (D. B.), “A Bronze Dancer from Alexandria", American Journal of Archaeology 54/4, 1950.

- TrüMPER (M.), "Bath and Bathing, Greek", in C. Smith (ed.), Encyclopedia of Global Archaeology, 2014.

- TRÜMPER (M.), "Complex Public Bath Buildings of the Hellenistic Period. A Case Study in Regional Differences", in M.-F. BousSAC, Th. FourNET, 
et B. Redon (eds.), Le Bain Collectif en Égypte, Études Urbaine 7, Cairo, 2009, p. 139-180.

- TURner (E. G.), Rea (J.), et al., The Oxyrhynchus Papyri XXVII, GraecoRoman Memoirs 39, London, 1962.

- Tyldesley (J. A.), Egyptian Games and Sports, Princes Risborough, 2007.

- Vandoni (M.), Feste pubbliche e private nei documenti greci. A cura di Mariangela Vandoni, Milano- Varese, 1964.

- Vendries (Chr.), “Questions d'iconographie musicale: L'apport des terres cuites à la connaissance de la musique dans l'Égypte hellénistique et romaine", Greek and Roman Musical Studies 1, 2013, p. 195-227.

- Versluys (J.), Aegyptiaca Romana. Nilotic scenes and the Roman views of Egypt, Religions in the Graeco-Roman World 144, Leiden Boston, 2002.

- WestermanN (W. L.), "Entertainment in the Villages of Graeco-Roman Egypt", Journal of Egyptian Archaeology 18, 1932, p. 16-27.

- Whitehouse (H.), "Mosaics and Painting in Graeco-Roman Egypt", in A. B. Lloyd (ed.), A companion to Ancient Egypt II, Wiley-Blackwell, 2010, p. 1008-1031.

- YegÜl (F.), Baths and Bathing in Classical Antiquity, New York, 1992.

- Y. VoloKhine, "Quelques aspects de Bès dans les temples égyptiens de l'époque Gréco-Romaine", in L. BRICAULT, M. J. VERSLUYS (eds.), Isis on the Nile. Egyptian Gods in Hellenistic and Roman Egypt, Proceedings of the IVth International Conference of Isis Studies, Leiden, 2010., p. 233256.

- Zaghloul (E. M.), Al-Hayah Al-Taqāfeyah wa Al-Riyādeyah wa AlFanneyah fi Oxyrinhus fi Al-'Asr Al-Romany hattā Nehāyat Al-Qarn AlTalet Al-mīlādi fi do do' Al-Wata'eq Al-Bardeyah, unpublished Master Thesis, Alexandria University, 2011. 


\section{الترويح في مصر اليونانية الرومانية}

نهى شلبي

مريم سعيد

لقد ثمن المصريون القدماء الأنشطة الترفيهية، مما إنعكس على مدى التقدم الذي وصلو إليه

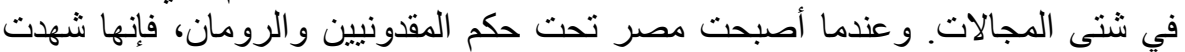

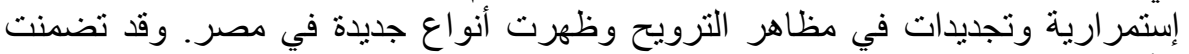

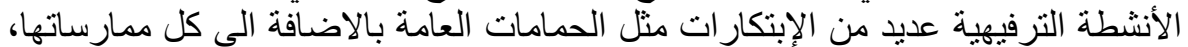

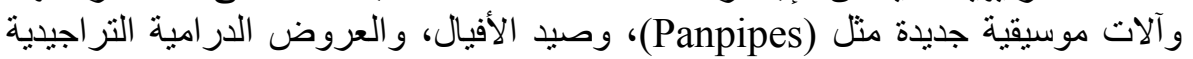

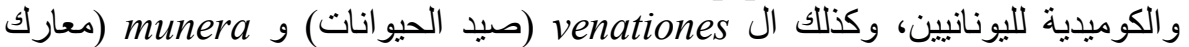
المحاربين)، والألعاب اللوحية الجديدة مثل cottabus لدى اليونانين و و Ludus Latrunculorum لدى الرومان، ولعبة الخيول التي تجر بالعجلات، وكذللك المرهرجانات العديدة مثل العدان

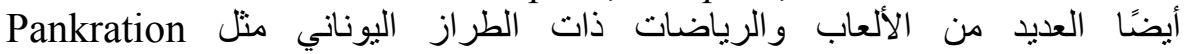

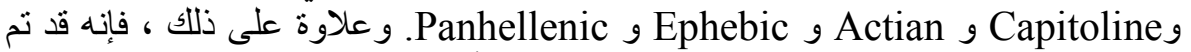

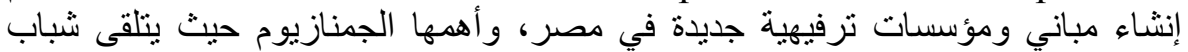

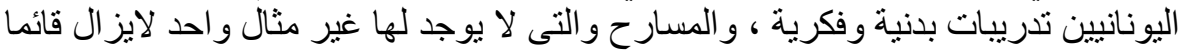

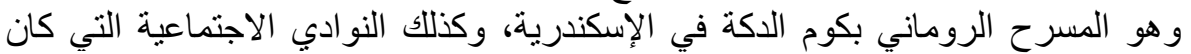

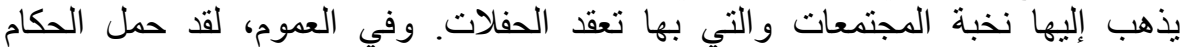

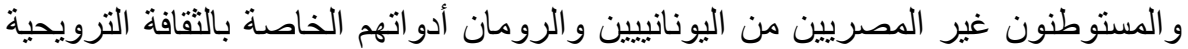

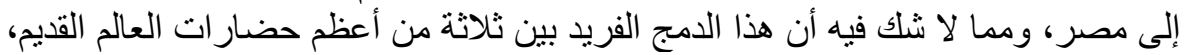

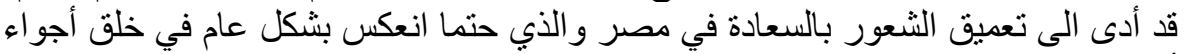
أفضل لقاطنيها. 